\title{
Do $\mathrm{NH}_{3}$ and chemical oxygen demand induce continuous release of phosphorus from sediment in heavily polluted rivers?
}

\author{
Wenqiang Zhang a , Xin Jin ${ }^{\mathrm{a}, \mathrm{b}}$, Xiaolei Zhu ${ }^{\mathrm{a}, \mathrm{b}}$, Xin Menga,b, Yaoyao Zhu ${ }^{\mathrm{a}, \mathrm{b}}$, Chao Zhang ${ }^{\mathrm{a}, \mathrm{b}}$, \\ Wenzhong Tang ${ }^{\mathrm{a}, *}$, Baoqing Shan ${ }^{\mathrm{a}, *}$ \\ a State Key Laboratory on Environmental Aquatic Chemistry, Research Center for Eco-Environmental Science, Chinese Academy of Science, P.O. Box 2871, \\ Beijing 100085, PR China \\ ${ }^{\mathrm{b}}$ University of Chinese Academy of Science, Beijing 100049, PR China
}

\section{A R T I C L E I N F O}

\section{Article history:}

Received 15 August 2016

Received in revised form 30 January 2017

Accepted 2 February 2017

Available online 16 February 2017

\section{Keywords:}

Ammoniacal nitrogen

Chemical oxygen demand

Phosphorus

River

Dissolved oxygen

Semi-arid region

\begin{abstract}
A B S T R A C T
While phosphorus (P) is a vital element in freshwater systems, excessive P loads will induce eutrophication. Large inputs of various pollutants, including $P$, to rivers in semi-arid regions result in complex environmental problems. In this study, we investigate dissolved oxygen (DO), ammoniacal nitrogen $\left(\mathrm{NH}_{3}\right)$, chemical oxygen demand (CODcr), soluble reactive $\mathrm{P}(\mathrm{SRP})$ in surface water and pore water, and sediment $\mathrm{P}$ in the Niuwei River, within the Hai River Basin. From our results we developed and tested a theory for P release in semi-arid regions driven by DO. The results show that $\mathrm{NH}_{3}$ and CODcr can cause variations in DO in surface water. The presence of pollutants at high concentrations caused seasonal hypoxia. Hypoxic river water induced adsorption and hydrolysis of $\mathrm{NaOH}-\mathrm{Pi}$ and labile organic $\mathrm{P}$ (L-Po), which then resulted in increased SRP concentrations in pore water and surface water. Overall, our results illustrate that $\mathrm{NH}_{3}$ and CODcr may be important for P adsorption and desorption and for management of water quality problems in rivers in semi-arid regions.
\end{abstract}

(C) 2017 Published by Elsevier B.V.

\section{Introduction}

Eutrophication of freshwater systems, as one of the most serious environmental issues in semi-arid region, is mainly caused by phosphorus (P) (Carpenter, 2008; Pernet-Coudrier et al., 2012). Rapid socioeconomic development, huge increases in population, and the systematic damming of rivers induce deterioration of freshwater ecosystems (Li et al., 2012; Pernet-Coudrier et al., 2012; Shan et al., 2012; Taylor et al., 2015). Over the last 30 years, numerous nutrient management schemes have been initiated in China, with the aim of improving water quality. The Chinese government is very concerned about controlling pollution inputs, and so regulations and projects have been implemented, such as the Chinese National Water Pollution Control and Technology Management Project. Despite recent sustained efforts to improve water quality, eutrophication still persists in rivers in semi-arid regions, and the water quality has deteriorated to such a degree that it is not suitable for any use (Han et al., 2013). Although external P inputs to rivers have been decreasing, internal release of $\mathrm{P}$ from sediment provides

\footnotetext{
* Corresponding authors.

E-mail addresses: wztang@rcees.ac.cn (W. Tang), bqshan@rcees.ac.cn (B. Shan).
}

sufficient reactive P to sustain harmful algal blooms (Read et al., 2014). Studies that provide information about the mechanisms and drivers of $\mathrm{P}$ adsorption and desorption in fluvial sediment in semi-arid regions are therefore urgently needed (Kraal et al., 2013; Ahlgren et al., 2005).

Biogeochemical cycles are generally driven by reducing and oxidizing conditions (Nielsen et al., 2010). Excessive nutrient inputs will consume oxygen and induce hypoxia in the bottom waters, with the result that $P$ is readily remobilized from sediments. This internal source of $\mathrm{P}$ will fuel high primary productivity and oxygen consumption; this is particularly relevant for the slow flowing rivers with numerous dams that are common in semi-arid regions of northern China (Gustafsson et al., 2012). Iron (Fe) and sulfur (S) may influence $\mathrm{P}$ adsorption and desorption. The reductive dissolution of Fe-oxides induces $P$ release under seasonal hypoxia (Cowan et al., 1996; McManus et al., 1997). In summer, the lower oxygen levels in bottom water induce high rates of sulfate reduction, with the result that there are fewer iron oxides to bind $P$ when sediment iron oxides are being converted to iron sulfides (Jensen et al., 1995; Rozan et al., 2002). In re-oxygenated conditions, the iron sulfides can be oxidized, at which point they create iron oxides that have the ability to sequester P (Dale et al., 2013). In addition, sulfuroxidizing bacteria can accumulate $\mathrm{P}$, which will be released from 
seasonally hypoxic sediment during summer (Schulz and Schulz, 2005). Recently, it was discovered that a filamentous bacterium from the Desulfobulbaceae family (cable bacteria) could control iron-P dynamics in sediments in a coastal hypoxic basin (Pfeffer et al., 2012; Seitaj et al., 2015; Sulu-Gambari et al., 2015).

The Hai River Basin (HRB) experiences severe water resource shortages, and water quality was seriously deteriorated. Excessive quantities of pollutants from agricultural activities and industrial development have been discharged into the system, to the degree that the river suffers from a mixture of pollutants at high concentrations. P biogeochemical cycling is much more complex in this type of river. Through long-term monitoring, we discovered that ammoniacal nitrogen $\left(\mathrm{NH}_{3}\right)$ and chemical oxygen demand (CODcr) were important components of the pollutant load in surface water. We also found that there were relationships between $\mathrm{NH}_{3}$, CODcr, and $\mathrm{P}$. In this contribution we present field data from a tributary of the HRB, the Niuwei River, and demonstrate the link between seasonal changes in concentrations of $\mathrm{NH}_{3}$, CODcr, dissolved oxygen (DO), $\mathrm{P}$ in surface and pore water, and $\mathrm{P}$ fractions in sediment. The results from this study will be very significant for pollutant control, especially $\mathrm{P}$, in rivers in semi-arid regions.

\section{Materials and methods}

\subsection{Study area}

The Niuwei River is the most polluted part of the Fuyang River and is contaminated by a wide range of pollutants. It flows through a fertile plain that easily supports intensive agriculture, mainly wheat, corn, and vegetables (Li et al., 2012). This region has a temperate continental monsoon climate and most of the rainfall falls during summer; precipitation in June, July, and August accounts for $70 \%$ of the annual precipitation (Chun et al., 2009). The water flows from south west to north east. There are dams and gates in this region that lead to fragmentation and instability of the river system. The Niuwei River was chosen for this study as it is representative of the conditions in the HRB in northern China.

\subsection{Field sampling}

The sampling sites were located on the main channel of the Niuwei River. In general, sampling sites should not be in dead water, backwater, or discharge outfall areas, and should be, as far as possible, on straight sections of the river where the flow is gentle and the channel is wide. We selected five sampling sites, the locations of which are presented in Fig. 1. We collected the sample at the middle of every-month from Jan-2014 to Dec-2015, which continue 2 years. Five sample sites distribute along the Niuwei River. The S1 and S2 were at the urban area of Xingtai City and Ren County. S3 was located at the transition area between the city and suburban region, and S4 and S5 were at suburban district. As a transition site, sediment was also collected at S3 in this research. We collected the water samples $(200 \mathrm{~mL})$ with an organic glass sampler (WB-PM, Beijing Splitter Instrument Co., Ltd.) from the middle of the river. The samples were stored at $4{ }^{\circ} \mathrm{C}$ in a refrigerator in our vehicle and were immediately transported to the laboratory, where analyses were carried out within two days. DO concentrations were measured in situ with a portable device (YSI ProPlus).

Surface sediments (about $2 \mathrm{~cm}$ ) were collected with PVC sampling tubes, the diameter and length were 6.3 and $60 \mathrm{~cm}$. There were three subsampling sites at each sampling site. Two subsamples collected at the same site were pooled and homogenized to obtain a representative sample. One sediment sample was used for extracted the pore water sample. Sediment samples for P analysis were kept in sealed plastic bags at $0^{\circ} \mathrm{C}$ during transport to the laboratory. Samples were freeze-dried at $-50^{\circ} \mathrm{C}$ (FD-1 freezedryer) on arrival at the laboratory. Dried samples were ground and passed through a 100-mesh sieve. Sediment sample for extracted pore water was deal as soon as possible. Quartered samples were taken as representative samples, and were stored in sealed plastic bags at room temperature until analysis. All the samples were collected from January 2014 to December 2015.

\subsection{Sample analysis}

\subsubsection{SMT fractions}

P fractions were determined as outlined in the Standards Measurements and Testing (SMT) protocol (Ruban et al., 2001a,b). Sediment $\mathrm{P}$ was classified into total $\mathrm{P}(\mathrm{TP})$, inorganic $\mathrm{P}(\mathrm{Pi})$, organic $\mathrm{P}(\mathrm{Po}), \mathrm{P}$ associated with $\mathrm{Ca}(\mathrm{HCl}-\mathrm{Pi})$, and $\mathrm{P}$ bound to $\mathrm{Fe}, \mathrm{Al}$ and Mn oxides and hydroxides ( $\mathrm{NaOH}-\mathrm{Pi}$ ). To determine TP, $0.2 \mathrm{~g}$ dry sample calcined at $450^{\circ} \mathrm{C}$ for $3 \mathrm{~h}$. The cool ash was transferred to a centrifuge tube, to which $20 \mathrm{~mL}$ of $3.5 \mathrm{~mol} \mathrm{~L}^{-1} \mathrm{HCl}$ was added. The tube shaken overnight ( $16 \mathrm{~h}$ ) and then was centrifuged at $2000 \mathrm{~g}$ for

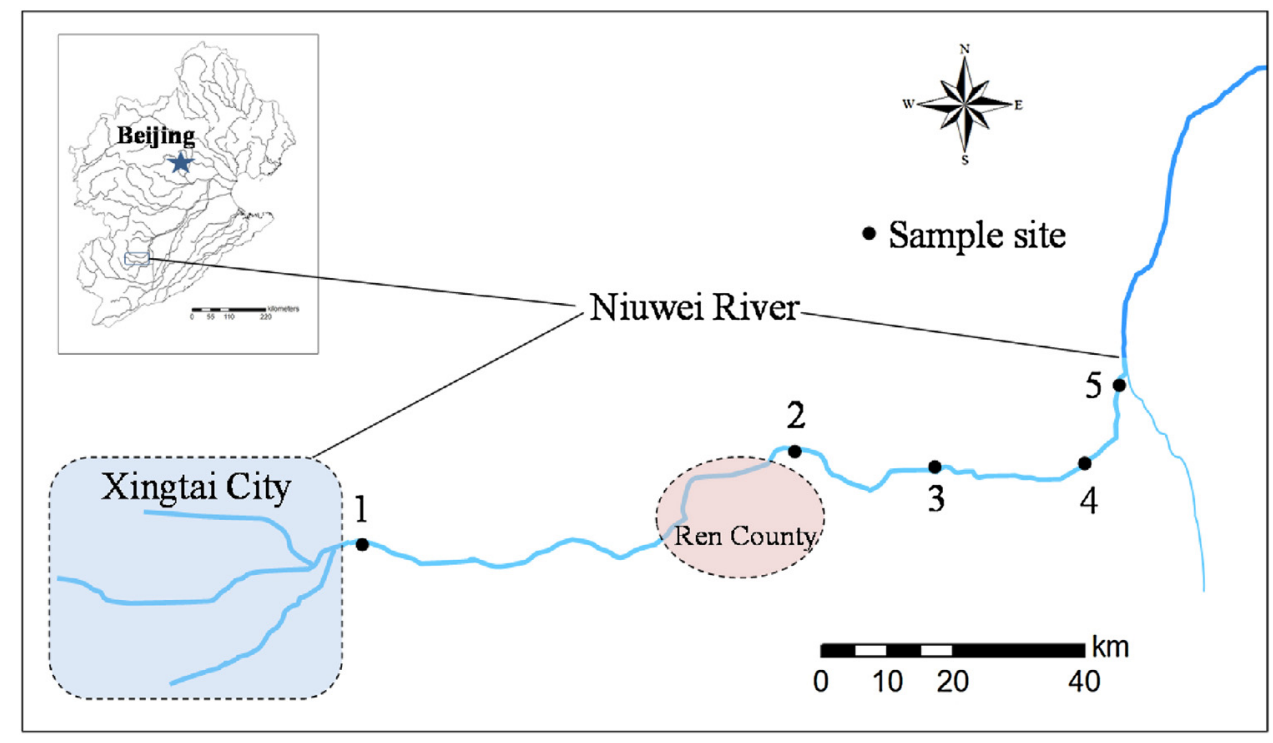

Fig. 1. The sample sites in Niuwei River. 
15 min. After centrifugation, the extract was collected for determination of TP. To measure Pi and Po, $0.2 \mathrm{~g}$ dry sample was put into a centrifuge tube, to which $20 \mathrm{~mL}$ of $1 \mathrm{~mol} \mathrm{~L}^{-1} \mathrm{HCl}$ was added. The tubes shaken overnight $(16 \mathrm{~h})$, and then were centrifuged at $2000 \mathrm{~g}$ for $15 \mathrm{~min}$. After centrifugation, the extract was collected for determination of Pi. The Po content was calculated as the difference between TP and Pi.

For determination of $\mathrm{HCl}-\mathrm{Pi}$ and $\mathrm{NaOH}-\mathrm{Pi}, 0.2 \mathrm{~g}$ dry sample were put into centrifuge tubes, to which $20 \mathrm{~mL}$ of $1 \mathrm{~mol} \mathrm{~L}^{-1} \mathrm{NaOH}$ were added. The tubes shaken overnight $(16 \mathrm{~h})$ and then centrifuged at $2000 \mathrm{~g}$ for $15 \mathrm{~min}$. After centrifugation, $\mathrm{NaOH}-\mathrm{Pi}$ was extracted from the supernatant, and $\mathrm{HCl}-\mathrm{Pi}$ was extracted from the residue. To determine $\mathrm{NaOH}-\mathrm{Pi}, 10 \mathrm{~mL}$ of the centrifuged liquid was separated with a pipette, to which $4 \mathrm{~mL}$ of $3.5 \mathrm{~mol} \mathrm{~L}^{-1} \mathrm{HCl}$ was added. The tube shaken vigorously for $20 \mathrm{~s}$, and allowed to stand overnight (16h). A brown precipitate appeared and settled, and then was centrifuged at $200 \mathrm{~g}$ for $15 \mathrm{~min}$. $\mathrm{NaOH}-\mathrm{Pi}$ was determined in the supernatant. The residue was washed with $12 \mathrm{~mL}$ of $1 \mathrm{~mol} \mathrm{~L}^{-1} \mathrm{NaCl}$, and stirred for $5 \mathrm{~min}$. It was then centrifuged at $2000 \mathrm{~g}$ for $15 \mathrm{~min}$, and the supernatant was discarded. Then, $20 \mathrm{~mL}$ of $1 \mathrm{~mol} \mathrm{~L}^{-1} \mathrm{HCl}$ was added to the tube and stirred overnight $(16 \mathrm{~h})$. After centrifugation at $2000 \mathrm{~g}$ for $15 \mathrm{~min}, \mathrm{HCl}-\mathrm{Pi}$ was determined in the extract. All the $\mathrm{P}$ in the extract was measured by molybdate colorimetry (Aspila et al., 1976).

\subsubsection{Fractionation of $P o$}

Po was operationally defined into three fractions, including labile Po (L-Po), moderately labile Po (M-Po), and nonlabile Po (N$\mathrm{Po}$ ). To determine L-Po, duplicate samples of $1.0 \mathrm{~g}$ were placed into two $100 \mathrm{~mL}$ centrifuge tubes. To one tube, $50 \mathrm{~mL}$ of $0.5 \mathrm{~mol} \mathrm{~L}^{-1}$ $\mathrm{NaHCO}_{3}$ was added and the sample was placed horizontally on a reciprocating mechanical shaker for $16 \mathrm{~h}$. The sample was centrifuged at $7000 \mathrm{rpm}$ for $15 \mathrm{~min}$ and the supernatant was filtered into a $50-\mathrm{mL}$ volumetric flask. To determine $\mathrm{L}-\mathrm{Pi}$, an aliquot containing between 2 and $40 \mu \mathrm{g}$ of $\mathrm{P}$ was added to a $50-\mathrm{mL}$ volumetric flask; five drops of $p$-nitrophenol indicator were added to the flask and the $\mathrm{pH}$ was adjusted with $2 \mathrm{~mol} \mathrm{~L}^{-1} \mathrm{HCl}$ until the indicator color just changed from pale yellow to colorless. Approximately $40 \mathrm{~mL}$ of deionized water was added to the flask, followed by $8 \mathrm{~mL}$ of reagent B. After $20 \mathrm{~min}$, the P concentration was determined on a calibrated spectrophotometer at $880 \mathrm{~nm}$. A blank containing the $0.5 \mathrm{~mol} \mathrm{~L}^{-1} \mathrm{NaHCO}_{3}$ extracting solution was analyzed along with the sample. To determine total L-P in the extract, $0.5 \mathrm{~g}$ of $\mathrm{K}_{2} \mathrm{~S}_{2} \mathrm{O}_{8}$ was added with a calibrated scoop to a $25-\mathrm{mL}$ volumetric flask. An appropriate aliquot of the extract was added into the flask, and then $3 \mathrm{~mL}$ of $2.5 \mathrm{~mol} \mathrm{~L}^{-1} \mathrm{H}_{2} \mathrm{SO}_{4}$ was added. The sample was digested on a hot plate at $>150^{\circ} \mathrm{C}$ for $20-30 \mathrm{~min}$, until the vigorous boiling subsided. The sample was cooled and $5 \mathrm{~mL}$ of deionized water were added. After mixing, five drops of $p$-nitrophenol indicator were added to the flask and the $\mathrm{pH}$ was adjusted with $5 \mathrm{~mol} \mathrm{~L}^{-1} \mathrm{NaOH}$. Approximately $10 \mathrm{~mL}$ of deionized water were added to the flask, followed by $4 \mathrm{~mL}$ of reagent B. After $20 \mathrm{~min}$, the P concentrations were determined with a calibrated spectrophotometer at $880 \mathrm{~nm}$. The difference between the total L-P by persulfate oxidation and L-Pi gives an estimate of L-Po. To determine the M-Po concentrations, $50 \mathrm{~mL}$ of $1 \mathrm{~mol} \mathrm{~L}^{-1} \mathrm{HCl}$ was added to the residue from the L-P extraction, and the sample was placed on a reciprocating mechanical shaker for $3 \mathrm{~h}$. An aliquot of $1 \mathrm{~mol} \mathrm{~L}^{-1} \mathrm{HCl}$ was used to rinse the residue from the filter paper used in the L-P extraction. After $3 \mathrm{~h}$, the sample was centrifuged at $7000 \mathrm{rpm}$ for $15 \mathrm{~min}$, and the supernatant was filtered into a $50-\mathrm{mL}$ volumetric flask. The TP and Pi in the extract were determined as previously described. Po extracted in the $1 \mathrm{~mol} \mathrm{~L}^{-1} \mathrm{HCl}$ is considered part of the M-P fraction. The residue was rinsed from the $\mathrm{HCl}$ extraction with deionized water, centrifuged for $5 \mathrm{~min}$, after which point the supernatant solution was discarded. Fifty milliliters of $0.5 \mathrm{~mol} \mathrm{~L}^{-1} \mathrm{NaOH}$ was added to the residue, and the sample was shaken for $16 \mathrm{~h}$. At the end of the extraction time, the sample was centrifuged at $7000 \mathrm{rpm}$ for $15 \mathrm{~min}$. The supernatant contains both $\mathrm{M}-\mathrm{Po}$ (fulvic acid $\mathrm{P}$ ) and N-Po (humic acid $\mathrm{P}$ ). To separate these fractions, an aliquot of the $\mathrm{NaOH}$ extract was removed and acidified to $\mathrm{pH} 0.2$ with concentrated $\mathrm{HCl}$. The acidified sample was centrifuged at $7000 \mathrm{rpm}$ for $15 \mathrm{~min}$. The TP in both the $\mathrm{NaOH}$ extract and the acidified sample were determined as previously described. The TP in the acidified sample is a measure of fulvic acid P. Humic acid P was estimated by subtracting fulvic acid $\mathrm{P}$ from the TP measured in the $\mathrm{NaOH}$ extract. To determine highly-resistant, $\mathrm{N}-\mathrm{Po}$, the residue from the $\mathrm{NaOH}$ extraction was rinsed with deionized water, shaken for $5 \mathrm{~min}$, and centrifuged, after which the supernatant solution was discarded. The residue was placed in a crucible and ashed at $550^{\circ} \mathrm{C}$ for $1 \mathrm{~h}$. The ash was dissolved by shaking in $1 \mathrm{~mol} \mathrm{~L}^{-1} \mathrm{H}_{2} \mathrm{SO}_{4}$ for $24 \mathrm{~h}$, and $\mathrm{P}$ in solution was measured as previously described (Pierzynski, 2000).

The detail information about "SMT fractions" and "Fractionation of Po" were shown in support information.

\subsubsection{Water sample analysis}

To determine soluble reactive $\mathrm{P}$ (SRP) in surface water, water samples were filtered through a $0.45-\mu \mathrm{m}$ synthetic fabric filter membrane. Concentrations of SRP were then measured using the molybdate colorimetry method (Wei, 2002). Concentrations of $\mathrm{NH}_{3}$ were measured using the spectrophotometric blue method (Wei, 2002) after the water samples were filtered through a $0.45-\mu \mathrm{m}$ synthetic fabric filter membrane. CODcr was determined by the colorimetry method (HACH DR2800) after digestion by COD chromate reagent (HACH DRB200, catalog number 21258-25). Samples of surface sediment (the top $2 \mathrm{~cm}$ ) firstly picked out impurity, such as the plant debris, and then centrifuged at $5000 \mathrm{rpm}$ for $10 \mathrm{~min}$ to extract the pore water and the supernatant was filtered through Whatman No. 41 quantitative paper into a $50-\mathrm{mL}$ volumetric flask. Concentrations of SRP in pore water were then measured by the molybdate colorimetry method. The $\mathrm{NH}_{3}$ and CODcr monitoring data for the HRB were processed by ArcGIS 10.0.

\section{Results}

\subsection{Temporal and spatial variations of the different indexes in surface and pore water}

The concentrations of pollutants showed a tendency to increase and then decrease between sampling sites. Concentrations of $\mathrm{NH}_{3}$, CODcr, SRP in surface water, and SRP in pore water were higher at S2 than at S1, and then the concentrations decreased from S3 to S5. These pollutant concentrations exceeded the thresholds for Class V of the Environmental Quality Standards for Surface water (National Standard of the People's Republic of China, GB3838-2002). The average concentration of $\mathrm{NH}_{3}$ in $\mathrm{S} 1$ to $\mathrm{S} 5$ was $6.95,7.12,6.79$, 6.13 and $3.93 \mathrm{mg} \mathrm{L}^{-1}$, respectively. The average concentration of CODcr in S1 to S5 was 69.75, 72.46, 66.42, 60.92 and $46.67 \mathrm{mg} \mathrm{L}^{-1}$, respectively. The average concentration of SRP in surface water and in pore water were in S1 to S5 were 2.15, 2.41, 1.93, 1.85 and $1.15 \mathrm{mg} \mathrm{L}^{-1}$ and $8.13,8.24,8.04,7.88$ and $7.00 \mathrm{mg} \mathrm{L}^{-1}$, respectively. In contrast, DO concentrations first decreased and then increased, and minimum and maximum values were observed at S2 and S5, respectively. The average concentration of DO from S1 to S5 was $1.26,1.07,1.36,1.64$ and $2.02 \mathrm{mg} \mathrm{L}^{-1}$, respectively.

We studied changes in the concentrations of the variables at site S3. DO concentrations were subject to seasonal variations, and declined in summer followed by re-oxygenation (increases) in fall and winter. For Jan to Dec, the concentration of DO was $1.75,2.10$, $2.35,2.20,1.95,1.35,0.65,0.30,0.30,0.75,1.15,1.45 \mathrm{mg} \mathrm{L}^{-1}$, respectively. $\mathrm{NH}_{3}$, CODcr, SRP in surface water, and SRP in pore water 

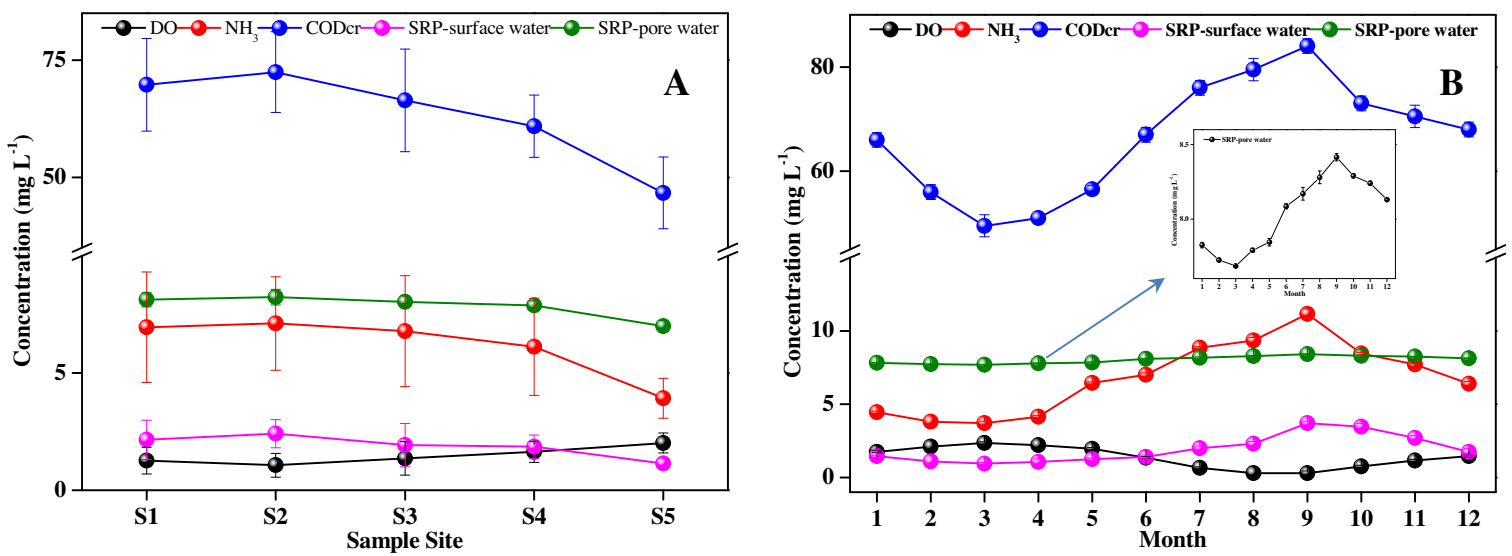

Fig. 2. Spatial (S1-S5: A) and temporal (S3: B) variation of DO, $\mathrm{NH}_{3}, \mathrm{CODcr}$, SRP in surface water and SRP in pore water in Niuwei River.

decreased in spring and then increased to their maximum values in summer, and then decreased again. For Jan to Dec, the concentration of $\mathrm{NH}_{3}$ was $4.45,3.80,3.70,4.15,6.45,7.00,8.85,9.35,11.15$, $8.45,7.70,6.40 \mathrm{mg} \mathrm{L}^{-1}$, respectively. The concentration of CODcr was $66.0,56.0,49.5,51.0,56.5,67.0,76.0,79.5,84.0,73.0,70.5$, $68.0 \mathrm{mg} \mathrm{L}^{-1}$, respectively. The average concentration of SRP in surface water and in pore water were $1.45,1.10,0.95,1.05,1.25,1.40$, $2.00,2.30,3.70,3.45,2.70,1.75$ and $7.83,7.73,7.69,7.79,7.85,8.09$, $8.17,8.28,8.42,8.29,8.24,8.13 \mathrm{mg} \mathrm{L}^{-1}$, respectively. The pollutant concentrations at S3 exceeded the thresholds for Class V. The data are shown in Fig. 2 and SI Tables 1 and 2.

\subsection{Phosphorus in surface sediments}

Information about $\mathrm{P}$ fractions in sediment at S3 is presented in Figs. 3 and 4. The main component of $\mathrm{Pi}$ was $\mathrm{NaOH}-\mathrm{Pi}$, the concentration of which was $590.7 \mathrm{mg} \mathrm{kg}^{-1}$, followed by $\mathrm{HCl}-\mathrm{Pi}$, the concentration of which was $424.3 \mathrm{mg} \mathrm{kg}^{-1}$. Concentrations of Po were lowest $\left(164.8 \mathrm{mg} \mathrm{kg}^{-1}\right)$. Po was divided into three parts, namely N-Po, M-Po, and L-Po, the concentrations of which were $126.7,32.3$, and $5.7 \mathrm{mg} \mathrm{kg}^{-1}$, respectively.

Spatial variation in the different $\mathrm{P}$ components in surface sediments is presented in Fig. 4. The concentrations of the $\mathrm{NaOH}-\mathrm{Pi}$ and Po fractions from the SMT method showed little variation from January to December. NaOH-Pi increased slightly from January to March, followed by a decrease, and then a further increase. The $\mathrm{NaOH}-\mathrm{Pi}$ concentrations ranged from 587.85 to $593.10 \mathrm{mg} \mathrm{kg}^{-1}$, with an average of $590.51 \mathrm{mg} \mathrm{kg}^{-1}$. Concentrations of Po ranged from 160.40 to $167.75 \mathrm{mg} \mathrm{kg}^{-1}$, and the average concentration was $164.71 \mathrm{mg} \mathrm{kg}^{-1}$. Variations in the components of Po, M-Po and L-Po,

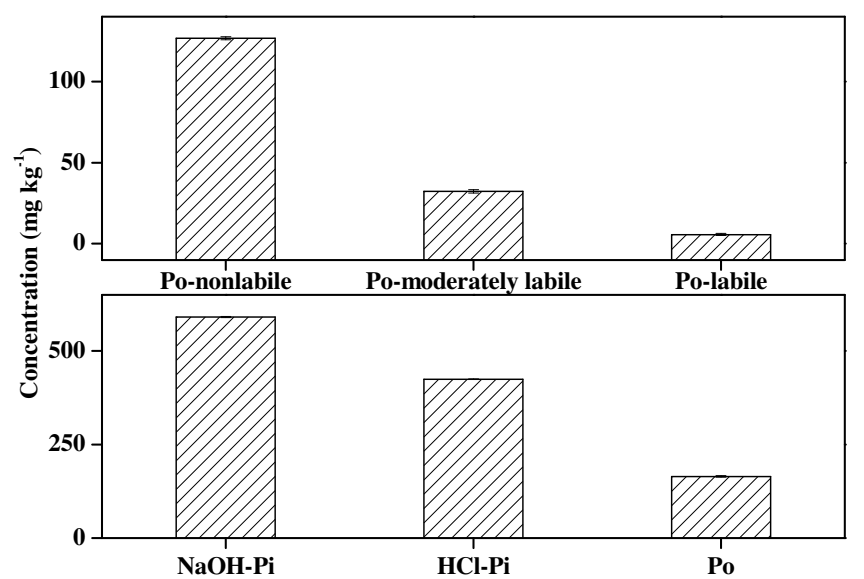

Fig. 3. Fractionation of surface sediment in $\mathrm{S} 3$ in Niuwei River.

followed the same pattern as concentrations of Po. Concentrations of M-Po and L-Po ranged from 30.00 to $33.70 \mathrm{mg} \mathrm{kg}^{-1}$ and from 4.65 to $6.85 \mathrm{mg} \mathrm{kg}^{-1}$, respectively. The average M-Po and L-Po concentrations were 32.20 and $5.67 \mathrm{mg} \mathrm{kg}^{-1}$, respectively. As stable components of $\mathrm{P}$, there were no obvious changes in both $\mathrm{HCl}-\mathrm{Pi}$ and N-Po.

\section{Discussion}

Concentrations of $\mathrm{NH}_{3}, \mathrm{CODcr}$, and SRP, in surface water and pore water were higher in urban areas (S1 and S2) than in suburban
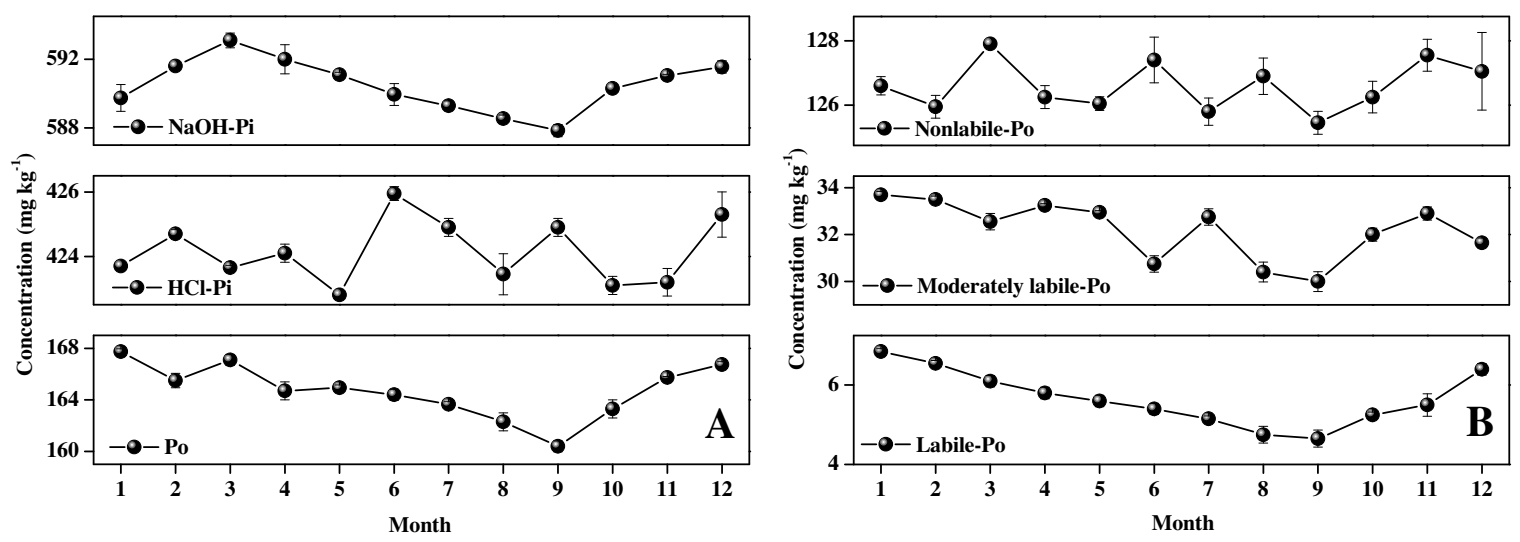

Fig. 4. Temporal variation of NaOH-Pi, HCl-Pi, Po (A) and Nonlabile-Po, Moderately labile-Po, labile-Po (B) in surface sediment in S3 in Niuwei River. 
Table 1

Pearson correlation coefficients for physicochemical characteristics in the Niuwei River ( $n=600)$.

\begin{tabular}{|c|c|c|c|c|c|}
\hline & DO & $\mathrm{NH}_{3}$ & CODcr & SRP-surface water & SRP-pore water \\
\hline DO & 1 & $-0.537^{* *}$ & $-0.432^{* *}$ & $-0.371^{* *}$ & $-0.299^{* *}$ \\
\hline $\mathrm{NH}_{3}$ & & 1 & $0.830^{* *}$ & $0.854^{* *}$ & $0.827^{* *}$ \\
\hline CODcr & & & 1 & $0.814^{* *}$ & $0.879^{* *}$ \\
\hline SRP in surface water & & & & 1 & $0.794^{* *}$ \\
\hline SRP in pore water & & & & & 1 \\
\hline
\end{tabular}

"Correlation is significant at the 0.05 level (2-tailed).

** Correlation is significant at the 0.01 level (2-tailed).

Table 2

Pearson correlation coefficients for physicochemical characteristics at site $3(n=240)$.

\begin{tabular}{|c|c|c|c|c|c|c|c|c|c|c|}
\hline & DO & $\mathrm{NH}_{3}$ & CODcr & SRP-surface water & SRP-pore water & $\mathrm{NaOH}-\mathrm{Pi}$ & $\mathrm{HCl}-\mathrm{Pi}$ & $\mathrm{N}-\mathrm{Po}$ & M-Po & L-Po \\
\hline DO & 1 & $-0.952^{* *}$ & $-0.969^{* *}$ & $-0.838^{* *}$ & $-0.941^{* *}$ & $0.812^{* *}$ & -0.069 & 0.234 & $0.679^{* *}$ & $0.763^{* *}$ \\
\hline $\mathrm{NH}_{3}$ & & 1 & $0.915^{* *}$ & $0.846^{* *}$ & $0.937^{* *}$ & $-0.763^{* *}$ & 0.067 & -0.279 & $-0.722^{* *}$ & $-0.852^{* *}$ \\
\hline CODcr & & & 1 & $0.826^{* *}$ & $0.922^{* *}$ & $-0.870^{* *}$ & 0.164 & -0.231 & $-0.648^{*}$ & $-0.636^{*}$ \\
\hline SRP-surface water & & & & 1 & $0.893^{* *}$ & $-0.635^{*}$ & -0.091 & -0.239 & $-0.525^{*}$ & $-0.636^{*}$ \\
\hline SRP-pore water & & & & & 1 & $-0.714^{* *}$ & 0.167 & -0.034 & $-0.732^{* *}$ & $-0.764^{* *}$ \\
\hline $\mathrm{NaOH}-\mathrm{Pi}$ & & & & & & 1 & -0.037 & 0.068 & 0.129 & 0.055 \\
\hline $\mathrm{HCl}-\mathrm{Pi}$ & & & & & & & 1 & 0.019 & -0.334 & 0.050 \\
\hline N-Po & & & & & & & & 1 & 0.020 & 0.233 \\
\hline M-Po & & & & & & & & & 1 & $0.694^{*}$ \\
\hline L-Po & & & & & & & & & & 1 \\
\hline
\end{tabular}

N-Po: Nonlabile-Po; M-Po: Moderately labile-Po; L-Po: Labile-Po.

* Correlation is significant at the 0.05 level (2-tailed).
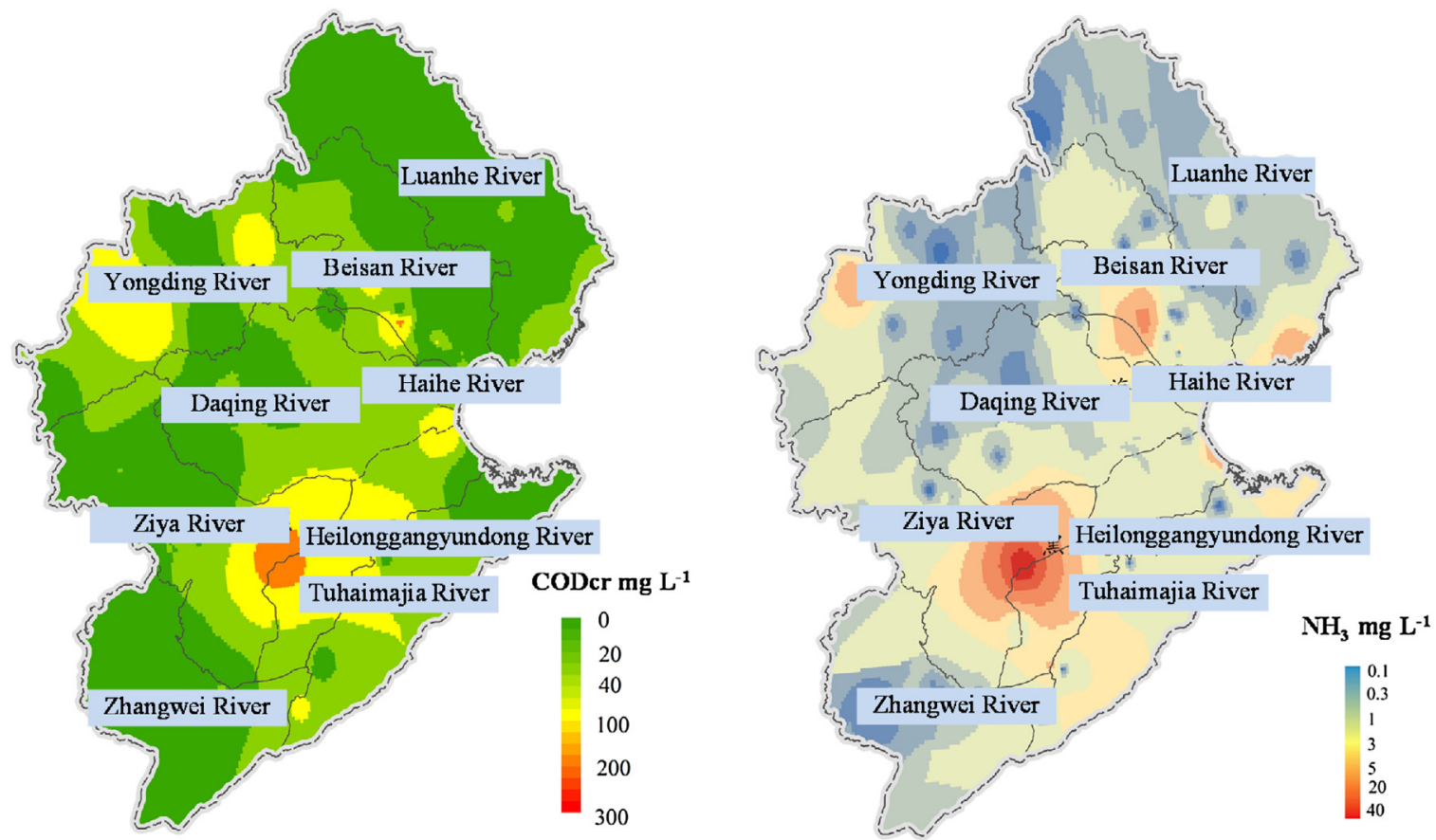

Fig. 5. The distribution of $\mathrm{NH}_{3}$ and CODcr in surface sediments from river systems in Hai River Basin.

areas (S3, S4, and S5). There are many industries, such as paper and steel, in Xingtai City and Ren County that discharge large quantities of pollutants. A proportion of the wastewater and domestic sewage are discharged in their untreated forms into the river. Further, the self-purification capacity of the part of the river that flows through the city is reduced by the artificial river bank, which are smaller river curvature, little vegetation index, hardening of cement and little landscape heterogeneity, a simple littoral zone and lack of change in river morphology (Zhang et al., 2014). These factors mean that there is nitrogen $(\mathrm{N})$ and $\mathrm{P}$ accumulation in the river water (Li et al., 2012). Although agriculture wastewater is discharged to the river, the presence of a more integrated littoral zone, which has variety vegetation and high landscape heterogeneity, in that particular area means that the river has a higher self-purification ability (Zhang et al., 2014). Nutrient concentrations were therefore higher in suburban areas than in urban areas. In contrast, DO concentrations were higher in suburban areas than in urban areas, which reflects the different pollutants and variations in the river ecosystem. Pearson correlation analysis showed that there were negative relationships between $\mathrm{DO}$ and $\mathrm{NH}_{3}, \mathrm{CODcr}$, and SRP in surface water and pore water $\left(p<0.01, \mathrm{R}^{2}=-0.537,-0.432,-0.371\right.$, -0.299 , respectively) (Table 1 ). The pollutants, such as $\mathrm{NH}_{3}$ and CODcr, consume the DO, so the higher pollutant concentrations will induce DO decline in the river water. The positive relationship 
between the pollutants indicates a common origin and/or mutual transformations (such as SRP in surface water and SRP in pore water, $\left.\mathrm{R}^{2}=0.893, p<0.01\right)$.

Site S3 was chosen for an in-depth study of the relationships between the variables. Unlike lakes and estuaries, hypoxia and anoxia in river water are driven by catchment inflows and stratification (Scicluna et al., 2015). Seasonal hypoxia in shallow rivers may be induced by pollution inputs, seasonal rainfall, and temperature (Wang et al., 2016). In the Niuwei River, the DO concentrations in surface water varied by $\pm 0.73 \mathrm{mg} \mathrm{L}^{-1}$. The negative relationships between DO and both $\mathrm{NH}_{3}$ and CODcr $\left(p<0.01, \mathrm{R}^{2}=-0.952\right.$, and -0.969 , respectively) also indicate that pollution may influence the DO contents. The negative relationship between DO and SRP $\left(p<0.01, R^{2}=-0.838\right)$ in surface water indicates that DO may trigger release or adsorption of SRP. $\mathrm{P}$ recycling in sediments is enhanced under anoxic conditions in the absence of amorphous $\mathrm{Fe}^{3+}$, which has a strong affinity for dissolved phosphate and promotes enhanced microbial phosphate release (Ingall et al., 1993; Steenbergh et al., 2011). Further, $\mathrm{Fe}^{3+}$ and $\mathrm{Mn}^{5+}$ oxides may be directly involved in the adsorption and hydrolysis of Po compounds, and may influence P release from sediment (Olsson et al., 2010; Huang and Zhang, 2012). The influence of DO on SRP in surface water is mainly through its influence on the P concentrations in sediment. Decreases in DO cause increases in the SRP concentrations in pore water $\left(p<0.01, \mathrm{R}^{2}=-0.941\right)$. Further examination showed that DO was positively related to $\mathrm{NaOH}-\mathrm{Pi}, \mathrm{M}-\mathrm{Po}$, and L-Po $\left(p<0.01, \mathrm{R}^{2}=0.812,0.679\right.$, and 0.763 , respectively). Another important hint is the negative relationship between SRP in pore water and $\mathrm{NaOH}-\mathrm{Pi}, \mathrm{M}-\mathrm{Po}$, and L-Po $\left(p<0.01, \mathrm{R}^{2}=-0.714,-0.732\right.$, and -0.764 , respectively). $\mathrm{NaOH}-\mathrm{Pi}$ represents the $\mathrm{P}$ bound to $\mathrm{Al}, \mathrm{Fe}$, and Mn oxides or hydroxides, and Fe-P was the main form of $\mathrm{P}$ in the sediment (Ruban et al., 2001a). Fe-P and Al-P are also readily influenced by $\mathrm{pH}$ and the oxidation-reduction potential (Ruban et al., 1999) and can be released into pore water and surface water under reducing conditions. These results confirm that DO affects SRP concentrations in surface sediment through its influence on the $\mathrm{Fe} / \mathrm{Mn}$-Pi and L-Po in sediment. From the above examination of the river system, we obtained the following picture of the patterns of $P$ release in this heavily polluted river. A range of pollutants at high concentrations caused seasonal hypoxia and low DO concentrations. The low DO levels induced increases in the SRP in pore water because of $\mathrm{NaOH}-\mathrm{Pi}$ and L-Po adsorption and hydrolysis, which then caused increases in the SRP in surface water (Table 2).

$P$ from sediment remains a significant internal pollutant source while external sources are gradually decreasing. Pollution from $\mathrm{NH}_{3}$ and CODcr increases as economic and social development increase (Pernet-Coudrier et al., 2012). More than 50\% of the rivers in the HRB exceeded the Class V water quality thresholds for $\mathrm{NH}_{3}$ and CODcr (National Standard of the People's Republic of China, Environmental Quality Standards for Surface Water, GB3838-2002) (Fig. 5). The results of this study indicate that combined pollution will cause ongoing internal $P$ release, which will then induce environmental problems, such as eutrophication, in rivers. We suggest that reductions in concentrations of $\mathrm{NH}_{3}$ and CODcr may be critical for $\mathrm{P}$ control and management in heavily polluted rivers. It should be noted that the processes and mechanisms are complex, and biological and chemical processes need to be studied in detail (Kraal et al., 2013; Sulu-Gambari et al., 2015).

\section{Conclusions}

In this study, we tested and confirmed a P release theory for rivers in semi-arid regions driven by changes in DO. The results show that $\mathrm{NH}_{3}$ and CODcr may induce variations in DO in surface water. From our examination of the trends in the data, we built a conceptual model of the $P$ release system. The pollution triggered seasonal hypoxia and low DO levels, which then induced increases in SRP concentrations in pore water and surface water because of NaOH-Pi and L-Po adsorption and hydrolysis. At the watershed scale, $\mathrm{NH}_{3}$ and CODcr may be important for P control and management.

\section{Acknowledgments}

This study was supported by the National Natural Science Foundation of China (Grant No. 21507146) and the National Water Pollution Control and Management Technology Major Projects of China (2012ZX07203-011 and 2012ZX07203-003), and the Youth Innovation Promotion Association CAS (Wenzhong Tang, 2017059)

\section{Appendix A. Supplementary data}

Supplementary data associated with this article can be found, in the online version, at http://dx.doi.org/10.1016/j.ecoleng.2017.02. 003.

\section{References}

Ahlgren, J., Tranvik, L., Gogoll, A., Waldeback, M., Markides, K., Rydin, E., 2005. Sediment depth attenuation of biogenic phosphorus compounds measured by ${ }^{31}$ P NMR. Environ. Sci. Technol. 39, 867-872.

Aspila, K.I., Agemian, H., Chau, A.S.Y., 1976. A semi-automated method for the determination of inorganic organic and total phosphate in sediments. Analyst $101,187-197$

Carpenter, S.R., 2008. Phosphorus control is critical to mitigating eutrophication. Proc. Natl. Acad. Sci. U. S. A. 105, 11039-11040.

Chun, J.T., Xia, J., Xu, C.Y., Li, L., Wang, Z.G., 2009. Comparison and spatial-temporal variability of daily precipitation data of weather station and rain gauges in Haihe river basin. J. Geogr. Sci. 4, 1083-1092

Cowan, J.L.W., Pennock, J.R., Boynton, W.R., 1996. Seasonal and interannual patterns of sediment-water nutrient and oxygen fluxes in Mobile Bay, Alabama (U.S.A.): regulating factors and ecological significance. Mar. Ecol. Prog. Ser. 141, 229-245.

Dale, A.W., Bertics, V.J., Treude, T., Sommer, S., Wallmann, K., 2013. Modeling benthic-pelagic nutrient exchange processes and porewater distributions in a seasonally hypoxic sediment: evidence for massive phosphate release by Beggiatoa? Biogeosciences 10, 629-651.

Gustafsson, B.G., Schenk, F., Blenckner, T., Eilola, K., Meier, H.E., Muller-Karulis, B., Neumann, T., Ruoho-Airola, T., Savchuk, O.P., Zorita, E., 2012. Reconstructing the development of Baltic sea eutrophication 1850-2006. Ambio 41, 534-548.

Han, C., Geng, J.J., Ren, H.Q., Gao, S.X., Xie, X.C., Wang, X.R., 2013. Phosphate in sedimentary interstitial water of lake Taihu, a large eutrophic shallow lake in China. Environ. Sci. Technol. 47, 5679-5685.

Huang, X.L., Zhang, J.Z., 2012. Hydrolysis of glucose-6-phosphate in aged, acid-forced hydrolysed nanomolar inorganic iron solutions-an inorganic biocatalyst? RSC Adv. 2, 199-208.

Ingall, E.D., Bustin, R.M., Van Cappellen, P., 1993. Influence of water column anoxia on the burial and preservation of carbon and phosphorus in marine shales. Geochim. Cosmochim. Acta 57, 303-316.

Jensen, H.S., Mortensen, P.B., Andersen, F.Ø., Rasmussen, E., Jensen, A., 1995. Phosphorus cycling in a coastal marine sediment Aarhus Bay, Denmark. Limnol. Oceanogr. 40, 908-917.

Kraal, P., Burton, E.D., Rose, A.L., Cheetham, M.D., Bush, R.T., Sullivan, L.A., 2013. Decoupling between water column oxygenation and benthic phosphate dynamics in a shallow eutrophic estuary. Environ. Sci. Technol. 47, 3114-3121.

Li, W.Z., Li, X.Y., Wang, H.L., Su, J.J., 2012. Spatial distribution of the main contamination in aquatic environment in Fuyang River. J. Environ. Sci. 2, 2814-2819.

McManus, J., Berelson, W.M., Coale, K.H., Johnson, K.S., Kilgore, T.E., 1997. Phosphorus regeneration in continental margin sediments. Geochim. Cosmochim. Acta 61, 2891-2907.

Nielsen, L.P., Risgaard-Petersen, N., Fossing, H., Christensen, P.B., Sayama, M., 2010. Electric currents couple spatially separated biogeochemical processes in marine sediment. Nature 463, 1071-1074.

Olsson, R., Giesler, R., Loring, J.S., Persson, P., 2010. Adsorption, desorption, and surface-promoted hydrolysis of glucose-1-phosphate in aqueous goethite $(\alpha-\mathrm{FeOOH})$ suspensions. Langmuir 26, 18760-18770.

Pernet-Coudrier, B., Qi, W.X., Liu, H.J., Müller, B., Berg, M., 2012. Sources and pathways of nutrients in the semi-arid region of Beijing-Tianjin, China. Environ. Sci. Technol. 46, 5294-5301.

Pfeffer, C., Larsen, S., Song, J., Dong, M.D., Besenbacher, F., Meyer, R.L., Kjeldsen, K.U., Schreiber, L., Gorby, Y.A., El-Naggar, M.Y., Leung, K.M., Schramm, A., Risgaard-Petersen, N., Nielsen, L.P., 2012. Filamentous bacteria transport electrons over centimetre distances. Nature 491, 218-221. 
Pierzynski, G.M., 2000. Methods of Phosphorus Analysis for Soils, Sediments, Residuals and Waters., pp. 54-59.

Read, E.K., Ivancic, M., Hanson, P., Cade-Menun, B.J., McMahon, K.D., 2014 Phosphorus speciation in a eutrophic lake by ${ }^{31} \mathrm{P}$ NMR spectroscopy. Water Res. 62, 229-240.

Rozan, T.F., Taillefert, M., Trouwborst, R.E., Glazer, B.T., Ma, S., Herszage, J., Valdes, L.M., Price, K.S., Luther, G.W., 2002. III Iron-sulfur-phosphorus cycling in the sediments of a shallow coastal bay: implications for sediment nutrient release and benthic macroalgal blooms. Limnol. Oceanogr. 47, 1346-1354.

Ruban, V., López-Sánchez, J.F., Pardo, P., Rauret, G., Muntau, H., Quevauviller, Ph., 1999. Selection and evaluation of sequential extraction procedures for the determination of phosphorus forms in lake sediment. J. Environ. Monit. 1, 51-56.

Ruban, V., López-Sánchez, J.F., Pardo, P., Rauret, G., Muntau, H., Quevauviller, Ph., 2001a. Development of a harmonized phosphorus extraction procedure and certification of a sediment reference material. J. Environ. Monit. 3, 121-125.

Ruban, V., López-Sánchez, J., Pardo, P., Rauret, G., Muntau, H., Quevauviller, P., 2001b. Harmonized protocol and certified reference material for the determination of extractable contents of phosphorus in freshwater sediments-a synthesis of recent works. Fresenius' J. Anal. Chem. 370, 224-228.

Schulz, H.N., Schulz, H.D., 2005. Large sulfur bacteria and the formation of phosphorite. Science 307, 416-418.

Scicluna, T.R., Woodland, R.J., Zhu, Y., Grace, M.R., Cook, P.L.M., 2015. Deep dynamic pools of phosphorus in the sediment of a temperate lagoon with recurring blooms of diazotrophic cyanobacteria. Limnol. Oceanogr. 60, 2185-2196.
Seitaj, D., Schauer, R., Sulu-Gambari, F., Hidalgo-Martinez, S., Malkin, S.Y., Burdorf, L.D.W., Slomp, C.P., Meysman, F.J.R., 2015. Cable bacteria generate a firewall against euxinia in seasonally hypoxic basins. Proc. Natl. Acad. Sci. U. S. A. 112, $13278-13283$.

Shan, B.Q., Jian, Y.X., Tang, W.Z., Zhang, H., 2012. Temporal and spatial variation of nitrogen and phosphorus and eutrophication assessment in downstream river network area of north canal river watershed. Environ. Sci. 3, 352-358.

Steenbergh, A.K., Bodelier, P.L.E., Hoogveld, H.L., Slomp, C.P., Laanbroek, H.J., 2011. Phosphatases relieve carbon limitation of microbial activity in Baltic Sea sediments along a redox-gradient. Limnol. Oceanogr. 56, 2018-2026.

Sulu-Gambari, F., Seitaj, D., Meysman, F.J.R., Schauer, R., Polerecky, L., Slomp, C.P. 2015. Cable bacteria control iron-phosphorus dynamics in sediments of a coastal hypoxic basin. Environ. Sci. Technol. 50, 1227-1233.

Taylor, M., Christopher, T.P., Christine, R., Severin, S., Hans, H.D., Helen, R.P., Philippe, V.C., 2015. Global phosphorus retention by river damming. Proc. Natl. Acad. Sci. U. S. A. 112, 15603-15608.

Wang, H.J., Dai, M.H., Liu, J.W., Kao, S.J., Zhang, C., Cai, W.J., Wang, G.Z., Qian, W., Zhao, M.X., Sun, Z.Y., 2016. Eutrophication-driven hypoxia in the east China sea off the Changjiang estuary. Environ. Sci. Technol. 50, 2255-2263.

Wei, F.S., 2002. Water and Wastewater Monitoring Analysis Method. China Environment Science Press, Beijing.

Zhang, W.Q., Shan, B.Q., Zhang, H., Tang, W.Z., 2014. Phosphorus-31 nuclear magnetic resonance assignments of biogenic phosphorus compounds in sediment of an artificial Fuyangxin River, China. Environ. Sci. Pollut. Res. 21, 3803-3812. 